\title{
DIE BYBEL STEEDS IN DISKUSSIE: 'N DEKADE LATER
}

\author{
F.B. Doubell ${ }^{1}$ \\ ABSTRACT \\ THE BIBLE STILL IN DISCUSSION: \\ A DECADE LATER
}

This article highlights the relationship between theology and context. In 1990 politics played a considerable role in South Africa. Authors such as F.E. Deist argued that one's point of departure, whether theological or political, is crucial. In 1991 Deist wrote an article on the discussion of the Bible. He used three South African publications on Scripture to illustrate the ongoing discussion. The present article refers to Deist's article on the discussion of the Bible in 1990 and then examines this discussion ten years later. It is concluded that the discussion on Scripture in 1990 differs from that in the year 2000. According to Deist, opposing theologians had to realise that the Bible is both a divine and a human book. This is accepted today, but some theologians go further and argue that the Bible is merely another human book. In 1990 criticism was divided between those who overemphasized the divine aspect and those who emphasized both the divine and the human aspects. Today criticism is divided between those who accept both the divine and the human aspects of Scripture and those who reject them. Ten years ago a political point of departure was acceptable within the overemphasized political context. Today there are theological and political differences in opinion.

1 Dr. F.B. Doubell, Departement Dogmatologie, Fakulteit Teologie, Universiteit van die Vrystaat, Posbus 339, Bloemfontein 9300. E-pos: fbd@wsiglobal.com 
Discrepanties in de Bijbel zouden per definitie onacceptabel zijn, wanneer de Bijbel zou pretenderen met notariële precisie en wetenschappelijke exactheid zijn boodschap aan de mensheid bekend te maken. Het gaat in de theopneuste Schrift echter om "wijsheid tot zaligheid". "Wijsheid" is iets anders dan "exacte wetenschap". "Wijsheid" heeft voorrang op en strekt verder dan "wetenschap" ... Maar het zal niet onze kloppende redenering omtrent de foutloze inspiratie zijn, die het gezag van de Bijbel vestigt of bevestigt. Dat doet de Geest die ons de Bijbel toevertrouwt ... (Trimp 1992:133)

\section{INLEIDING}

Vrae rondom die gesag van die Skrif word in elke geslag opnuut gevra. In ons tyd en konteks is dit veral die manne van die sogenaamde Nuwe Hervorming wat hierdie vrae weer op die spits dryf. Met hul boek Die Nuwe Hervorming (2002) onder redaksie van Piet Muller, vra hul kritiese vrae wat die tradisionele Christelike geloof uitdaag. In hierdie klimaat van kritiese vrae het heelwat teoloë opgestaan om hulle geloof in die gesag van die Skrif te herbevestig. Een so 'n geskrif kom uit die pen van Adrio König, te wete Ek glo die Bybel — ondanks al die vrae (2002); 'n ander een is So glo ons onder redaksie van Piet Meiring (2001). Al drie hierdie boeke is tiperend vir ons tyd, 'n tyd waarin kritiese vrae ernstige aanvalle op die tradisionele geloof loods. Albei laasgenoemde boeke wend 'n poging aan om die kritiese vrae ernstig op te neem sonder om die geloof te laat vaar. Aan die ander kant van die spektrum staan eersgenoemde boek gereed om die tradisionele geloof te laat vaar. In hierdie artikel wil ek spesifiek konsentreer op die Skrifleer. König se boek handel slegs oor die Skrifleer terwyl die ander twee boeke ' $n$ wye reeks temas aansny. In albei hierdie boeke is daar egter 'n hoofstuk wat spesifiek oor die Skrifleer handel. In So glo ons word die Skrifleer deur Hermie van Zyl hanteer, en in Die Nuwe Hervorming kom die hoofstuk oor die Skrif uit die pen van Sakkie Spangenberg.

In 1991 skryf F.E. Deist oor drie resente Suid-Afrikaanse artikels oor die Skrif. In hierdie artikel wil ek dieselfde poging aanwend en die vraag beantwoord of die teologiese debat rondom die Skrif in Suid-Afrika na 'n dekade enigsins verander het. Die probleemvraag lê op die terrein van die verhouding tussen teologie en konteks. Rondom 1990 was die Suid Afrikaanse samelewing oorgepolitiseerd. Deist vergelyk drie standpunte rondom die Skrif met mekaar en kies einde ten 
laaste vir dié standpunt wat sy filosofiese uitgangspunt duidelik stel - al is hierdie filosofiese uitgangspunt polities en nie teologies gemotiveerd nie. Vandag wentel die diskussie nie meer so sterk rondom politiese of filosofiese uitgangspunte nie, maar wel rondom teologiese verskille. Enkele Nederlandse skrywers word deurgaans aangehaal. Die doel hiermee is om aan te toon dat die Nederlandse diskussie van die Skrifleer in dieselfde tyd deurgaans oor teologiese verskilpunte gegaan het en nie oor polities of filosofiese uitgangspunte nie. Die oorgepolitiseerde Suid Afrikaanse debat het dus meer met die konteks te doen gehad as met die wêreldwye teologiese debat. Die Nederlandse teoloë word egter nie bespreek nie; hulle word slegs bygetrek om die teologiese ontwikkeling binne Suid-Afrikaanse konteks te verhelder.

\section{2. 'N BLIK OP ENKELE SUID-AFRIKAANSE SKRIFBESKOUINGS RONDOM 1990, ALDUS F.E. DEIST}

Deist beskryf en vergelyk die Skrifbeskouings van drie teoloë rondom 1990, naamlik J.H. van Wyk (1990), P.C. Potgieter (1989) en I.J. Mosala (1989). Hiermee wil hy 'n bydrae lewer tot die Suid-Afrikaanse teologiese debat oor die Skrif. Hy vergelyk hierdie "samespreking" uit die negentigerjare met die politieke samesprekings van daardie tyd. Daarom kies hy vir 'n gesprek tussen twee blanke teoloë, naamlik Van Wyk (uit die Gereformeerde Kerke) en Potgieter (uit die NG Kerk) en 'n swart teoloog naamlik Mosala (uit die Metodiste Kerk). Behalwe vir die feit dat die gesprek oor drie kerkgrense en twee kleurgrense heen gaan, wys Deist ook daarop dat die "blanke" teoloë dieselfde agterhaalde epistemologiese vertrekpunt deel terwyl Mosala reeds 'n paradigmaskuif meegemaak het. Hoewel Deist nie saamstem met al Mosala se gedagtes oor die Skrif nie, verkies hy Mosala se vertrekpunt bo die van Van Wyk en Potgieter. 'n Kort weergawe van Deist se beskrywing van die drie Skrifbeskouings sal bogenoemde belig.

\subsection{Deist se beskrywing van Van Wyk se Skrifbeskouing}

Deist beskryf Van Wyk se Skrifbeskouing aan die hand van laasgenoemde se boek Die Woord is waardevol: 'n Dogmatiese besinning oor die 
reformatoriese Skrifbeskouing (1990). Volgens Deist is die sleutelbegrip in Van Wyk se Skrifbeskouing die Goddelike openbaring (vgl. Deist 1991:931). Van Wyk erken dat geen rasionele argument ons kan oortuig van die openbaringsgestalte van die Skrif nie. Slegs die Skrif se selfgetuienis en die gelowige aanvaarding daarvan bring ons tot hierdie slotsom (Van Wyk 1990:47e.v.). Deist wys daarop dat Van Wyk homself hiermee distansieer van twee standpunte, naamlik die van die fundamentalisme wat die Skrifgesag rasioneel wil beveilig én die van teoloë wat die Skrif slegs beskou as menslike getuienis van die openbaring (Deist 1991:932-933). Deist waardeer Van Wyk se gedagtes rondom:

- die Bybel as religieuse dokument;

- die fout om Skrifbewyse op te stapel oor sake wat buite die heilshistoriese skopus van die Skrif lê;

- die feit dat teoloë bewus moet wees van hulle eie voorveronderstellings;

- kennisname dat 'n mens se eie epistemologiese vertrekpunt 'n mens se resultate kleur;

- die gebruik van grondige eksegetiese beginsels;

- die gevaar dat afgeleide interpretasies van die Skrif gesien word as openbaring. (Vgl. Deist 1991:933.)

Aan die ander kant maak Deist enkele kritiese opmerkings teenoor Van Wyk se standpunt:

- Dat Van Wyk pleit vir 'n nie-filosofiese teologiese epistemologie sonder om nader in te gaan op wat dit nou eintlik is;

- Dat Van Wyk vashou aan 'n kultureel bepaalde gesagsbegrip van die Skrif en dat hy daarmee tog verval in 'n filosofiese epistemologie;

- Dat Van Wyk nie ingaan op die aard van teologiese uitsprake nie en dat hy gevolglik nie uitklaar wat die status van teologiese kennis is nie;

- Indien teologiese kennis subjektief is, is dit 'n vraag hoe die Bybelskrywers aan hierdie subjektiwiteit ontkom het én indien hulle wel daaraan ontkom het, is dit 'n vraag of ons nie terug is by ' $n$ meganiese Skrifbeskouing nie; 
- Is dit dus nie tog noodsaaklik om te vra na die aard van kennis nie en gevolglik belangrik om ons besig te hou met filosofiese epistemologie nie? (Deist 1991:934-935.)

\subsection{Deist se beskrywing van Potgieter se Skrifbeskouing}

Potgieter se Skrifbeskouing word beskryf aan die hand van sy boek Skrif, dogma en verkondiging uit 1989. Deist sien "gesag" as die sleutelbegrip in Potgieter se Skrifbeskouing. Gesag funksioneer volgens Potgieter slegs in die verhouding tussen 'n meerdere en 'n mindere. Dit is ook waar van Goddelike gesag wat die terrein is waarbinne ons die Skrifgesag vind (vgl. Deist 1991:936 \& Potgieter 1990:8). Die Bybelskrywers het nie die Woord van God ervaar en daarvan getuig nie; hulle het dit ontvang en dit weergegee. Die waarheid van die Bybel is nie relasioneel nie, maar objektief. Die Bybelskrywers het die Woord van God suiwer oorgedra, maar as gevolg van die gebrokenheid van die mens is die korrekte interpretasie van die Skrif noodsaaklik voor die Bybelleser die Woord van God suiwer ontvang. Hierdie "korrekte interpretasie" vereis bepaalde reëls en uitlegbeginsels waaraan voldoen moet word. Potgieter erken egter dat daar geen onfeilbare metode van Skrifuitleg bestaan nie. Vir die prediking om Woord van God te wees moet die eksegeet die Skrif uitlê en dan op die situasie van die dag toepas. Indien sosiale vraagstukke die vertrekpunt van eksegese word, is daar geen ware Woordverkondiging meer nie (vgl. Deist 1991:936-937).

Deist reken dat Potgieter alles in sy vermoë doen om die gesagvolheid van die Skrif as Woord van God te objektiveer. Hiervoor probeer hy om menslike aktiwiteit tot die minimum te beperk in die inskripturasie en die interpretasie van die Skrif (vgl. Deist 1991: 938).

Deist is myns insiens oormatig krities in sy beoordeling van Potgieter se Skrifbeskouing. Hy wys op die een teenstrydigheid na die ander in Potgieter se argumentasie terwyl hy in sy eie argumentasie oor die Skrif soortgelyk teenstrydig dink (vgl. Doubell 1995:41-88 \& 1999:243-249). Hy kritiseer Potgieter byvoorbeeld oor die volgende teenstrydighede: 
- Die Bybel is objektiewe Woord van God, maar die Bybelskrywers se eie subjektiewe menslikheid het 'n rol gespeel in die opskrifstelling daarvan.

- Die Bybel is duidelik in sigself, waar en sonder teenstrydigheid. Die gebrokenheid en sondigheid van die leser veroorsaak onduidelikheid, verkeerde en teenstrydige interpretasie. Deist vra na die nut van 'n duidelike Skrif indien dit onduidelik word sodra dit gelees word.

- Potgieter meen dat ons die Bybel korrek moet uitlê aan die hand van korrekte uitlegbeginsels wat ons uit die Skrif aflei. Deist vra hoe ons korrekte beginsels uit die Skrif kan aflei indien ons hulle reeds nodig het voor ons hulle begin aflei.

- Indien korrekte beginsels en 'n gesonde dogmatiek nodig is vir die verstaan van die Skrif, hoe kan ons beweer dat die Skrif duidelik is?

- Potgieter meen dat die verligting van die Heilige Gees ons bystaan in die korrekte verstaan van die teks. Waarom is korrekte uitlegbeginsels dan nog nodig ? (Vgl. Deist 1991:938-940.)

\subsection{Deist se beskrywing van Mosala se Skrifbeskouing}

Mosala se Skrifbeskouing word beskryf aan die hand van sy boek $B i$ blical hermeneutics and Black Theology in South Africa, uit 1989. Volgens Deist beskou Mosala die Skrif vanuit presies die teenoorgestelde hoek as Van Wyk en Potgieter. Laasgenoemde twee teoloë neem hulle vertrekpunt in die Goddelike openbaring en gesag terwyl eersgenoemde sy vertrekpunt neem in die menslike kant van die Skrif. Die sleutelbegrip in Mosala se Skrifbeskouing is die klassestryd. Die Skrif is nie die gevolg van 'n Goddelike openbaring nie, maar die produk van antieke voorbeelde van klassestryd. Sommige tekste is die produk van die onderdrukkende leiersklas wat die status quo wil handhaaf terwyl ander tekste die produk van die onderdrukte bevryders is. Laasgenoemde tekste en nie die hele Skrif nie, is bevrydende materiaal. Die soeke na 'n universele, gesagvolle en objektiewe Bybelse boodskap is gegrond in die Westerse soeke na die absolute gesag van die leiersklas. Die relevansie van die Skrif lê nie in sy idealistiese universaliteit nie, maar in sy historiese, politiese en ekonomiese tydgebondenheid. Aan- 
gesien sekere tekste in die Bybel vanuit die leiersklas spruit, kan onderdrukkers hul eie politiese en ekonomiese stelsels Bybels fundeer. Bevrydingsteologie wys juis daarop dat sulke tekste tydgebonde is en nie die klassestryd ontmasker nie. Daarom is dit belangrik om nie van die Bybelse boodskap te praat nie, maar van Bybelse boodskappe én nie van die Bybelse God nie, maar van Bybelse gode (vgl. Deist 1991:940-943).

Deist waardeer Mosala se gedagtes rondom:

- Die feit dat Mosala die rol van die leser ernstig opneem. 'n Mens kan nie van die Bybel praat sonder om die Bybel in aksie, die Bybel in gebruik deur' 'n leser, in ag te neem nie.

- Die feit dat Mosala sy voorveronderstellings op die tafel sit en duidelik noem watter keuse hy uitoefen ten opsigte van sy perspektief op die Skrif.

Hy kritiseer Mosala oor die volgende:

- Mosala verwerp die term "Woord van God" sonder om in te sien dat die term verskillend geïnterpreteer kan word. Hy verwerp die term op grond van die tradisionele verstaan daarvan terwyl hy dit binne sy eie teologie, vanuit 'n ander hoek beskou, tog sou kon aanvaar.

- Mosala verduidelik nie sy eie gedagtes rondom die verband tussen God, die Bybel, teologie, geloof en die leser nie. Dit beteken dat hy nie daarin slaag om die plek van die Bybel in ons verhouding met God aan te dui nie. Tradisioneel Westerse teologie beskryf hierdie verhouding in terme soos inspirasie, openbaring en gesag. Mosala se kritiek hierop is vir Deist legitiem, maar dit verskoon Mosala nog nie vir die feit dat hyself geen verband van sy eie aantoon nie.

- Mosala maak die "bevrydingstryd" die kriterium vir die kies van relevante tekste in ons verhouding met God. In dieselfde asem beskuldig hy Boesak en Tutu daarvan dat hulle ewekansig selektief met die Skrif omgaan. Dit is vir Deist onverstaanbaar hoekom Mosala die bevrydingstryd as enigste korrekte beginsel vir teksseleksie kies. Vir Deist is dié keuse soortgelyk ewekansig selektief. 
- Mosala erken dat sy hermeneutiese lens (bevrydingstryd) spruit uit sy ideologiese voorveronderstelling (historiese materialisme), maar Deist voel dat hierdie ideologiese wegspringplek dieselfde gevolg kan hê as tradisionele Westerse teologie. Deist waarsku dat so 'n ideologies-bepaalde hermeneutiese lens Boere-Calvinisme na apartheid gelei het.

\section{SLOTSOM OOR SKRIFBESKOUING RONDOM 1990}

Deist skilder die gesprek oor Skrifbeskouing rondom 1990 teen die destydse agtergrond van die politieke samesprekings oor samesprekings. Die jare kort voor 1994 is gedomineer deur politieke samesprekings oor samesprekings ten opsigte van die toekoms van Suid-Afrika. Hy kom tot die slotsom dat die gesprek oor die Skrif, soos die gesprek oor die Nuwe Suid-Afrika, nog nie gereed is vir 'n ronde tafel nie. Ook oor die Skrif moet daar nog eers samesprekings oor samesprekings wees. Sy slotsom is dat die volgende punte op ' $\mathrm{n}$ agenda vir samesprekings oor samesprekings oor dié saak moet wees:

- Die twee gereformeerde teoloë sal by Mosala moet leer om hulle naïef-realistiese/positivistiese vertrekpunt op die tafel te plaas. Hierdie vertrekpunt bring hul daartoe om die probleem van objektiwiteit versus subjektiwiteit nie aan te spreek nie.

- Albei sal Mosala se waarskuwing oor die ideologiese aard van voorveronderstellings en hermeneutiek ernstig moet opneem.

- Albei sal die menslikheid van die Skrif in heroorweging moet neem. Die feit dat God Homself in die geskiedenis deur gewone mense openbaar het, maak dit moeilik om 'n inspirasieleer te formuleer wat hul openbaringsbeskouing en gesagsbeskouing steeds orent hou.

- Albei sal moet erken dat daar beswaarlik 'n enkele dogmatiese of etiese standpunt is wat deur die hele Bybel ondersteun word. Die Bybel bied meer dikwels 'n verskeidenheid van moontlike antwoorde.

- Mosala sal duidelik moet uitspel waarom ons die Bybel lees. Hy wys op die menslikheid van die Bybel, maar hy klaar nie die verhouding tussen God en die Bybel uit nie. 
- Mosala sal sy materialistiese hermeneutiese sleutel in heroorweging moet neem, want dit bied nie ruimte vir die verskeidenheid van tekste in die Skrif nie.

- Sy ononderhandelbare keuse vir materialisme as enigste hermeneutiese sleutel bied geen ruimte vir gesprekvoering nie. Hy sal ten minste moet erken dat 'n pluralistiese samelewing ruimte moet laat vir 'n verskeidenheid van hermeneutiese sleutels.

Indien 'n mens Deist se agenda vir gesprekvoering oor gesprekvoering beskou, is die volgende sake oor die Skrifdebat rondom 1990 duidelik:

- Die epistemologie het op daardie stadium 'n essensiële plek in die teologiese debat ingeneem. Artikels uit dié tyd laat mens soms wonder of die teologiese debat ooit weer by ander sake as die voorvrae sou uitkom. Soos met politieke samesprekings oor samesprekings in dié tyd wou die teologiese debat net nie 'n aanvang neem nie.

- Veral binne die Suid-Afrikaanse konteks speel die tradisionele benadering in die Skrifdebat 'n prominente plek teenoor 'n bevrydingsteologiese benadering.

- Die teologie van bo en onder neem 'n belangrike plek in die debat in, maar dan gekoppel aan beide die verhouding God/mens en die verhouding verdrukker/verdrukte. Teologie van bo streef na 'n Skrifleer gekoppel aan tradisie, Goddelikheid, gesagvolheid, openbaring en inspirasie. Teologie van onder streef na 'n Skrifleer gekoppel aan bevryding, menslikheid, medemenslikheid, ideologiekritiek en epistemologie.

- Die verhouding tussen die Goddelikheid en die menslikheid van die Skrif speel, soos altyd, ' $n$ rol in die Skrifdebat, maar is nie so prominent soos die vrae rondom epistemologie, ideologie, bevryding en hermeneutiek nie.

De principiële geloofwaardigheid behoefde niet te worden aangetoond, want die is gegeven met de fundamentele aanvaarding van de Bijbel als Gods Woord tot ons. Maar deze principiële geloofwaardigheid vraagt wel om bevestiging in de praktische geloofwaardigheid van wat de Bijbel ons vertelt en voorhoudt ... De belangrijkste vraag bij het lezen van een teksteenheid in de Bijbel is daarom niet: wat hebben mensen eertijds daarbij beleefd en kunnen wij daarnog iets mee? maar: wat heeft God daarin tot ons te zeggen? (Loonstra 1994:212-213) 


\section{4. 'N BLIK OP ENKELE SUID-AFRIKAANSE SKRIFBESKOUINGS RONDOM 2000}

\subsection{Die Skrifbeskouing van Adrio König}

König se Skrifbeskouing word beskryf aan die hand van sy boek $E k$ glo die Bybel — ondanks al die vrae uit 2002. Die bedoeling van dié boek is om enersyds vaste bakens te bied in 'n tyd van twyfelvrae. Andersyds wil die boek nie 'n naïewe Skrifbeskouing voorhou wat nie rym met die werklike probleme rondom die Skrifleer nie. Hy reken dat 'n teoloog eers goed kennis moet maak met die Skrif en sy probleme voor hy 'n standpunt oor die Skrif moet waag. Hy stel dit duidelik:

Gereformeerde teoloë skryf te gou in hulle lewe oor die Bybel, lank voordat hulle intensiewe blootstelling aan die inhoud van die Bybel gehad het (König 2002:14).

Hierin het hy waarskynlik gelyk. Biblioloë beskuldig dogmatici dikwels daarvan dat hul idealistiese teorieë oor die Bybel formuleer sonder om werklik kennis te neem van die vrae wat met reg rondom die Skrif gevra kan word (vgl. Deist 1986:76-77).

Die sleutelterm in König se Skrifbeskouing is die verbond. Hy koppel die gesag, duidelikheid, noodsaaklikheid en genoegsaamheid van die Skrif direk aan die sentrale boodskap daarvan. Hoewel hy bewus is van die stryd rondom 'n soeke na die sentrum van die $\mathrm{Ou}$ Testament, kies hy onomwonde vir die verbond as sentrum, maar dan breed verstaan (vgl. König 2002:30-31). Die sentrale boodskap van die Skrif lê vir hom in die verhouding (verbond) tussen God, mens en aarde, terwyl Jesus Christus die kulminasiepunt binne hierdie verhouding is. Aan die hand van hierdie sentrum met sy kulminasiepunt formuleer hy ' $\mathrm{n}$ belangrike beginsel: dit wat herhaaldelik en in verskillende verbande voorkom, vorm 'n tradisie en kry teologiese betekenis. Dié beginsel help hom om onderskeid te tref tussen dit wat van belang is en dit wat minder belangrik is. Die betekenis van die kruisboodskap is byvoorbeeld volgens hierdie beginsel belangrik en gekoppel aan die sentrum van die Skrif. Die vraag na die ouderdom van die aarde daarenteen, lê weer ver van die sentrum af (vgl. König 2002:88-92). 
König maak erns met die ontstaan en die groei van die Skrif. Die beskuldiging van Deist dat sistematiese teoloë nie kennis neem van navorsing in die Bybelwetenskap nie, het nie op dowe ore geval nie. Die probleme rondom die twee skeppingsverhale, die belofte-vervullingskema, mondelinge oorlewering, die inter-testamentêre tyd, teenstrydighede in die Bybel, die gebruik van die Ou Testament in die Nuwe, ensovoorts kom almal ter sprake (vgl. König 2002:94-113).

König se Skrifbeskouing word eers duideliker in 'n volgende hoofstuk van sy boek, naamlik Wat glo ons oor die Bybel? Hierin pleit hy vir die gedagte dat die Bybel nie openbaring is nie, maar getuienis aangaande die openbaring van God. God het nie 'n boek uit die hemel aan ons geskenk nie, maar Homself in die geskiedenis aan ons geopenbaar. Hiervan getuig die Bybelskrywers. Hy wys ook daarop dat 'n formele belydenis oor die gesag van die Skrif, sonder dat dit in jou verhouding met God 'n rol speel, sinneloos is. Die inspirasie word deur hom erken en bely, maar hy wys terselfdertyd op die sinnelose redenasies rondom 'n bepaalde inspirasieteorie. Weer eens wys König daarop dat inspirasie met die sentrum en die boodskap van die Skrif te doen het en nie met presiese woorde of eksakte gegewens nie. Met dié standpunt maak König dit vir ons maklik om verby die oneffenhede van die Skrif te kyk en die belangrike lyne van God se openbaring in die geskiedenis raak te sien.

In die laaste dele van sy boek kyk König na uitlegteorie, verskille in die Skrif en probleemtekste. Telkens voer hy aan dat dit in die Skrif om die verhouding (verbond) tussen God, mens en skepping gaan. Verskille tussen tekste, verskillende vertalings en ander probleme rond om die verstaan van die teks verdwyn in die niet as ons aan die sentrale boodskap met sy kulminasiepunt in Christus vashou.

Enkele opmerkings rondom die Skrifbeskouing van König:

- Dit is belangrik om in te sien dat König se bydrae nie in die eerste plek vir teoloë bedoel is nie. Hoewel sy boek van grondige teologiese kennis getuig, is dit 'n populêre boek bedoel vir gelowiges.

- Desnieteenstaande doen König moeite om die bevindings in die Bybelwetenskap ernstig op te neem en in sy Skrifbeskouing te verreken. Hy gaan dieper in op sake soos die ontstaan en groei van die Bybel, oneffenhede in die Skrif en die hermeneutiek. 
- Hy slaag daarin om nie verstrengel te raak in teorieë oor die Bybel, sy inspirasie en gesag wat nie rym met Bybelwetenskaplike bevindings nie. Hy distansieer hom van 'n formele Skrifteorie wat nie prakties grondvat in verhouding tussen God, mens en skepping nie.

- Sy klemverskuiwing vanaf die gesag, duidelikheid, genoegsaamheid en noodsaaklikheid van die letter van die Skrif na die sentrale boodskap help ons om te ontsnap uit die twyfelvrae rondom randsake.

- Hy erken die probleme, historiese oneffenhede, teenstrydighede en ander probleme in die Skrif sonder om die geloof aan die Bybel as Woord van God prys te gee.

- Die enigste gevaar in sy standpunt kom na vore by die bepaling van 'n sentrum in die Skrif. Indien die gesag van die Skrif net op die sentrum betrek word en indien die sentrum altyd weer deur die mens bepaal word, lei dit noodwendig daartoe dat die mens self besluit wat hy as gesagvol aanvaar.

\subsection{Die Skrifbeskouing van Hermie van Zyl (2001)}

Van Zyl se Skrifbeskouing word beskryf aan die hand van 'n hoofstuk wat hy geskryf het in So glo ons - gelowig nagedink oor God, die Bybel en ons leefwêreld uit 2001. Hierin hanteer hy die Skrif onder die vraag: Is die Bybel nog God se Woord? Soos in die geval van König se bydrae, is So glo ons geskryf om vaste bakens te bied in 'n tyd waarin die Bybel met twyfelvrae gebombardeer word. Van Zyl begin sy hoofstuk met 'n persoonlike geloofsverklaring wat, myns insiens, dadelik aantoon hoe hy oor die Skrif dink. Enersyds bely hy dat die Bybel onontbeerlik vir die verstaan van God, die mens se bevryding en sy bestaan is. Die Bybel het die vermoë om die hart en wil van God bloot te lê omdat God homself verbind het aan die oorsprong, bewaring en werking daarvan. Tweedens wys hy daarop dat 'n mens jou moet inleef in die ervaringswêreld van die Bybelkarakters voor die Bybel tot jou sal spreek. Met hierdie twee gedagtes bevind Van Zyl homself iewers tussen 'n organiese en 'n aktualistiese beskouing van die Skrif. Hy erken dat God Homself aan die Bybel as sodanig verbind het, maar hy wys ook daarop dat die Bybel tot jou spreek (God se Woord word) wan- 
neer jy "korrek" daarmee omgaan. Hiermee wil hy 'n bepaalde punt tuis bring, naamlik dat die gesag van die Bybel direk gekoppel moet word aan die gebruik daarvan. In ander terme druk hy dit as volg uit:

\section{Mense weet van die Bybel, hulle plaas dit op 'n troontjie, sal selfs die gesag daarvan gloedvol verdedig, maar hulle leef nie meer in die idioom van die Bybel nie (Van Zyl 2001:74).}

In terme van Deist se beskrywing van eersgenoemde drie teoloë hierbo, sou 'n mens kon sê dat die sleutelterm in Van Zyl se Skrifbeskouing "praktiese Skrifstudie" is. Die gesag van die Skrif lê nie en behoort nie te lê in 'n formele teorie nie, maar word gekoppel aan die alledaagse omgang daarmee. Hy sluit sy gedagtes af met verwysing na Ricoeur wat wys op drie fases van Bybellees, die naïewe fase, die kritiese fase en 'n post-kritiese fase waarin daar met die insigte van die kritiese fase weer hernude verwondering oor die Skrif terugkeer. Dié verwysing is tekenend van Van Zyl se Skrifbeskouing, hy wil nie naïef wees oor die probleme rondom die Skrif nie en hy wil ook nie in 'n Skrifkritiese fase verval nie. Die Bybel vra om kritiese Skrifstudie, maar einde ten laaste moet ons in die praktyk weer terugkeer na 'n verwondering oor die Bybel as Woord van God — praktiese Skrifstudie.

Enkele opmerkings ten opsigte van die Skrifbeskouing van Van Zyl:

- Dit sou onbillik wees om Van Zyl se bydrae in So glo ons te beoordeel asof dit pretendeer om 'n volledig uitgewerkte Skrifleer te wees. Sy bydrae is nie bedoel as 'n akademies uitgewerkte Skrifbeskouing nie. Dit is eweneens belangrik om in te sien dat hierdie artikel nie fokus op die vraag of elke aspek van die Skrifleer by 'n bepaalde skrywer aan die bod kom nie. Dit gaan hier eerder oor 'n kern Skrifbeskouing soos dit by elke skrywer na vore kom. Enige iets meer sou die bedoeling van beide Van Zyl en Spangenberg se bydraes te bowe gaan.

- In die lig van bogenoemde is dit ook belangrik om te vermeld dat Van Zyl 'n biblioloog en nie 'n sistematikus is nie. Deist het reeds in 1986 daarop gewys dat sistematici soms met 'n teorie oor die Bybel begin en daarna probeer om die Bybel daarin te maak pas terwyl biblioloë daagliks met die vrae in die Bybel worstel (vgl. Deist 1986:77). Van Zyl se bydrae wys duidelik dat hy die probleme wat kritiese Skrifstudie oplewer, ernstig opneem. 
- Om kritiese Skrifstudie ernstig op te neem, eindig so dikwels by niks anders as akademiese retoriek oor die Skrif nie. Van Zyl se Skrifbeskouing slaag myns insiens goed daarin om 'n kritiese ingesteldheid met 'n gelowige verwondering te kombineer. Dit is die kombinasie waarmee ons in 'n tyd van naïewe fundamentalisme en kritiese vertwyfeling baie ver kan kom.

- Met inagneming van die eersgenoemde punt hierbo, sou ek Van Zyl se Skrifbeskouing graag verder uitgewerk wou sien.

\subsection{Die Skrifbeskouing van Sakkie Spangenberg (2002)}

Spangenberg se Skrifbeskouing word beskryf aan die hand van 'n hoofstuk wat hy geskryf het in Die Nuwe Hervorming onder redaksie van Piet Muller uit 2002. Daar word ook terugverwys na sy boek Perspektiewe op die Bybel — God se Woord in mensetaal uit 1998. Teenoor König en Van Zyl, skaar Spangenberg hom by dié groepering van teoloë wat twyfelvrae rondom die Skrif op die spits dryf. Spangenberg begin sy hoofstuk, Die Bybel en die Nuwe Hervorming, met 'n historiese konstruksie van die ontwikkeling van kerk en wetenskap, naamlik deur pre-moderne, moderne en postmoderne fases. Dié konstruksie kom by andere ook voor (vgl. Du Toit 2000:13-61), maar alle historici is nie so seker dat die geskiedenis van die wetenskap so oorvereenvoudig voorgestel kan word nie (vgl. Britz 2002:358-360). Met dié konstruksie neergelê as evangelie, kan Spangenberg 'n eietydse Skrifbeskouing aanbied.

Die sleutelterm in Spangenberg se Skrifbeskouing is "mensewoord". Die skrywers van die Bybelboeke en die oorspronklike lesers het met God in 'n verhouding gestaan. Die Gees werk wanneer ons hierdie dokumente van gelowiges van ouds lees. Dit is die inspirasie. Die boeke self is nie geïnspireerd nie, want God werk met mense en nie met lewelose dinge soos tekste nie. Die skrywer kan deur middel van sy teks die denke van die leser verruim, soos in die Boek Jona, of Rut. Die tekste kom uit 'n bepaalde godsdienstige era en dit moet in ag geneem word by die lees daarvan. Jesus het byvoorbeeld 'n soort hervormde Judaïsme beoefen. Aanvanklik was die Christendom en die Judaïsme twee vertakkings binne dieselfde godsdiens, maar later (rondom 80-100 n.C.) het daar 'n breuk tussen die twee gekom. Die 
Johannesevangelie is tydens hierdie breuk geskryf en daarom vind ons polemiese tekste soos Joh. 14:6 en Joh. 8:44. Christene kan wel bely dat Jesus vir hulle die weg, die waarheid en die lewe is, maar hul kan dit nie gebruik om ander godsdienste te demoniseer nie (vgl. Spangenberg 1998:52-73 \& 2002:103-108).

Die Bybel is deur mense geskryf wat in 'n verhouding met God gestaan het en daarvan getuig het. Hulle getuienis is vir ons belangrik want dit vorm die basisdokument van ons godsdiens. Ons moet dié boeke lees teen hul agtergrond en soos enige ander boeke met die hulp van moderne literatuurwetenskap. Die tekste is egter niks meer of minder nie as gewone mensewoorde (vgl. Spangenberg 1998:111118 \& 2002:109).

Enkele opmerkings ten opsigte van die Skrifbeskouing van Spangenberg:

- Soos König en Van Zyl wil Spangenberg aandag vra vir die historiese konteks, bedoeling van die skrywer en eerste lesers van die Bybelse tekste.

- Soos König en Van Zyl wil Spangenberg wys op die belang daarvan dat moderne uitlegmetodes by die lees van die Bybel gebruik moet word.

- Soos König en Van Zyl wil Spangenberg aantoon dat die Bybelteks geen invloed op ons lewens sal hê solank dit 'n toe boek bly nie.

- Anders as König en Van Zyl wil Spangenberg egter nie aanvaar dat daar 'n verskil is tussen hierdie en enige ander boek nie. Hoogstens is dit die oorspronklike basisdokument van die Christelike godsdiens en niks meer nie.

- Anders as König en Van Zyl wil Spangenberg ook niks daarvan weet dat God op 'n manier betrokke was by die ontstaan, groei en bewaring van hierdie boek nie. God werk nie met lewelose dinge soos tekste nie, maar met mense.

- Anders as König en Van Zyl wil Spangenberg ook nie aanvaar dat die gesag van die Skrif staan en val by die uniekheid van die Heer van die Skrifte nie. Jesus is wel belangrik vir ons, maar ander kan sonder Hom klaarkom. 


\section{SLOTSOM OOR SKRIFBESKOUING RONDOM 2000}

Hierdie afdeling hoef nie lank te wees nie. Die enkele opmerkings by Spangenberg se Skrifbeskouing dui reeds aan wat die debat oor die Skrif rondom 2000 behels. In sy artikel van 2002 wys Britz op dieselfde debat en die twee kante wat ter sprake is. In hierdie artikel verwys ek slegs na drie onlangse geskrifte oor die Skrif; Britz toon duidelik aan dat dit oor meer as drie geskrifte gaan. Dit gaan oor twee uiteenlopende standpunte binne die NG Kerk (vgl. Britz 2002: 361-367). Met die skryf van hierdie artikel het Spangenberg uit die NG Kerk bedank. Dit maak egter geen verskil nie, want dit gaan oor twee breë strome met Spangenberg as een eksponent van een van die twee strome.

\subsection{Het die debat rondom die Skrif verander?}

Rondom 1990 maak Deist van die politieke konteks gebruik om gesprekvoering oor gesprekvoering rondom die Skrif aan te moedig. Volgens hom het die kloof binne die debat in die epistemologie gelê. Hy toon aan dat twee teoloë nie uit hul naïef-realistiese vertrekpunt wil kom nie, terwyl 'n derde teoloog reeds die nuwe paradigmaskuif meegemaak het. Enige persoon wat vertroud is met die akademiese en populêre geskrifte van F.E. Deist, sal weet dat Deist nie die inspirasie of gesag van die Skrif ontken het nie én ook nie die uniekheid van Christus nie. Wat rondom 1990 'n storm in 'n teekoppie was, het rondom 2000 in 'n magtige seestorm ontaard. In 1991 reken Deist dat ons nog nie gereed is vir gesprek rondom die Skrif nie; in 2004 het gespreksgenote rondom die Skrif eerder van mekaar weggedryf as nader aan mekaar gekom. Rondom 1990 wou Deist en sy medestanders pleit dat teoloë nie net die goddelikheid van die Skrif moet raaksien nie, maar ook 'n oog moet hê vir die menslikheid van die Skrif. Rondom 2004 erken teoloë beide die goddelikheid en die menslikheid van die Skrif, maar sommige pleit dat God homself hoegenaamd nie met dooie dinge soos tekste besighou nie. Rondom 1990 was apartheid, of eerder die aftakeling daarvan, bykans die enigste tema in Suid-Afrika. Die samelewing en akademiese gesprekvoering was oorgepolitiseer. Politieke en filosofiese uitgangspunt was sen- 
traal in die Skrifdebat; vandag is 'n teologiese uitgangspunt, geloof of ongeloof, sentraal. Die Suid-Afrikaanse konteks is vandag minder gepolitiseer en dus kan die akademiese gesprek homself weer besighou met sy eie temas. So sluit die teologie in Suid Afrika weer aan by die wêreldwye teologiese debat. In die Skrifleer behels dit die vraag "Is die Bybel Woord van God of gewoon menslike woorde?" Daarmee hou die teologie homself wêreldwyd op die terrein van die Skrifleer besig en daarby het die Suid-Afrikaanse debat homself weer aangesluit. Die konteks het verander en die teologie hou hom weer met teologiese probleme besig. Weer eens is dit duidelik dat teologie en konteks nou met mekaar verweef is.

Van een aantal vragen waar de Schrift ons voor stelt, die ook bij Loonstra op indringende wijze aan de orde worden gesteld, zullen we ons niet gemakkelijk kunnen afmaken. De weg waarop we daarmee bezig hebben te zijn, zal geen ander begin kunnen nemen dan in de eigen verstaanshorizont van de Heilige Geest die getuigt in het hart van de gelovigen, dat het Woord betrouwbaar is, dat de God van het Woord betrouwbaar is en dat Christus zich laat kennen door en in het Woord. Dat weten heet geloven... de uitlegger van het Woord zal er de dienaar van moeten zijn (Maris 1998:48).

\section{BIBLIOGRAFIE}

\section{BRITZ R M}

2002. Twee standpunte oor die Skrif ... en 'n dilemma vir die NG Kerk. NGTT 43(3\&4):354-367.

\section{DeIST F E}

1986. Kan ons die Bybel dan nog glo? —onderweg na'n gereformeerde Skrifbeskouing. Pretoria: Van Schaik.

1991. The Bible in discussion. Three recent South African publications on Scripture. HTS 47(4):933-949.

\section{Doubell F B}

1995. Die Skrifbeskouing van F.E. Deist. Ongepubliseerde M.Th.-skripsie. Bloemfontein: UV. 
1999. Woord van God of woord oor God — op soek na 'n eietydse Skrifmodel. Ongepubliseerde D.Th. Bloemfontein: UV.

Du ToIT B

2000. God? Geloof in 'n postmoderne tyd. Bloemfontein: CLF.

KÖNIG A

2002. Ek glo die Bybel —ondanks al die vrae. Wellington: Lux Verbi.

LOONSTRA B

1994. De geloofwaardigheid van de Bijbel. Zoetermeer: Boekencentrum.

MARIS J W

1998. Geloof en Schriftgezag. Apeldoorn: TUA.

Mosala I J

1989. Biblical hermeneutics and black theology in South Africa. Grand Rapids: Eerdmans.

MÜLLER P (RED.)

2002. Die Nuwe Hervorming. Pretoria: Protea.

POTGIETER P C

1990. Skrif, dogma E verkondiging. Kaapstad: Lux Verbi.

\section{SPANGENBERG I}

1998. Perspektiewe op die Bybel — God se Woord in mensetaal. Pretoria: Van Schaik. 2002. Die Bybel en die Nuwe Hervorming. In: P. Muller (red.), Die Nuwe Hervorming (Pretoria: Protea).

TRIMP C

1992. Heilige Geest en Heilige Schrift. In: W.H. Velema (red.), Hoe staan wij ervoor? (Barneveld: De Vuurbaak).

VAN WYK J H

1990. Die Woord is waardevol: 'n Dogmatiese besinning oor die reformatoriese Skrifbeskouing. Potchefstroom: PU vir $\mathrm{CHO}$.

VAN ZYL H C

2001. Is die Bybel nog God se Woord? In: P. Meiring (red.), So glo ons (Vereeniging: CUM).

Trefwoorde

Dogmatiek

Skrifleer

Konteks

NG Kerk
Keywords

Systematic Theology

Scripture

Context

Dutch Reformed Church 